\title{
Evaluation of The Predictive Power of Blood Urea Nitrogen/Albumin Ratio for in-Hospital Mortality in Critically III Patients
}

\section{Kritik Bakım Hastalarında Kan Üre Azotu/Albumin Oranının Hastane İçi Mortaliteyi Tahmin Gücünün Değerlendirilmesi}

\author{
Zerrin Defne Dundar ${ }^{1}$, Kadir Kucukceran $^{1}$, Mustafa Kursat Ayranci ${ }^{1}$
}

${ }^{1}$ Necmettin Erbakan University, Meram Faculty of Medicine, Department of Emergency Medicine, Konya, Turkey

Address correspondence to: Zerrin Defne Dundar, Necmettin Erbakan University, Meram Faculty of Medicine, Department of Emergency Medicine, Konya, Turkey e-mail: zerdef@hotmail.com

Geliş Tarihi/Received: 5 May 2021 Kabul Tarihi/Accepted: 5 June 2021

\begin{abstract}
Öz
Amaç: Bu çalışmada, kritik bakım hastalarında yoğun bakım ünitesi (YBÜ) yatışında ölçülen kan üre azotu (BUN)/albümin oranının hastane içi mortaliteyi tahmin etme açısından prognostik değerinin değerlendirilmesi amaçlandı.

Hastalar ve Yöntem: Bu retrospektif gözlemsel çalışma, bir üniversite hastanesinin acil servisinde (AS) gerçekleştirildi. Altı ay (1 Temmuz 2019 - 31 Aralık 2019) boyunca acil AS-YBÜ'ye yatırılan hastalar çalışmaya dahil edildi. BUN/albümin oranının hesaplanmasında YBÜ'ye kabul öncesi ölçülmüş olan BUN ve albümin değerleri esas alındı. Çalışmanın birincil sonucu hastane içi mortaliteydi.

Bulgular: Çalışmaya toplam 572 hasta dahil edildi. Dahil edilen hastaların ortanca yaşı 66 (54-77) yıldı ve bunların 362'si $(\% 63,3)$ erkekti. Genel hastane içi mortalite oranı $29.0 \%$ (166 hasta) idi. Vefat edenlerin ortanca BUN seviyesi hayatta kalanlardan daha yüksekti $(38,2(21,4-59,7)$ ve $21,9(14,9-36,9) \mathrm{mg} / \mathrm{dL}$, $p<0,001)$. Vefat edenlerin ortanca albümin seviyesi hayatta kalanlardan daha düşüktü $(2,9(2,3-3,5)$ ve 3,7 $(3,2-4,0) \mathrm{g} / \mathrm{dL}, \mathrm{p}<0,001)$. Vefat edenlerin ortanca BUN/albümin oranı hayatta kalanlardan daha yüksekti (13.33 (6.69-22.99) ve 6.21 (3.83-11.21), p<0.001). Eğri altında kalan alanların sıralaması albümin $(0,742)$, BUN/albümin oranı $(0,720)$ ve BUN $(0,678)$ idi. Hastane içi mortaliteyi tahmin etme açısından hesaplanan kesim değerleri, albümin için $3,2 \mathrm{~g} / \mathrm{dL}$, BUN/albümin oranı için 10 ve BUN için $32 \mathrm{mg} / \mathrm{dL}$ idi. Sonuç: Sonuç olarak, YBÜ'ye yatış sırasında saptanan hipoalbüminemi, kritik hastalarda hastane içi mortalite ile ilişkilidir. Yüksek BUN ve BUN/albümin oranı da bu hastalarda hastane içi mortalitenin öngörücüleridir; ancak BUN ve BUN/albümin oranı hipoalbüminemiden daha üstün değildir.

Anahtar Kelimeler: Kan üre azotu, albümin, oran, yoğun bakım, mortalite

Abstract

Aim: In this study, it was aimed to evaluate the prognostic value of blood urea nitrogen (BUN)/albumin ratio measured in critically ill patients during intensive care unit (ICU) admission in terms of predicting in-hospital mortality.

Patients and Methods: The study was conducted at the emergency department (ED) of a university hospital. Patients admitted to the ED-ICU for 6 months (July 1, 2019 and December 31, 2019) were included in the study. BUN and albumin levels measured before admission to the ICU were used in the calculation of BUN/albumin ratio. The primary outcome was in-hospital mortality.

Results: A total of 572 patients was included in the study. The median age of included patients was 66 $(54-77)$ years, and $362(63.3 \%)$ of them were male. The overall in-hospital mortality rate was $29.0 \%(166$ patients). The median BUN level of non-survivors was higher than that of survivors $(38.2(21.4-59.7)$ vs. $21.9(14.9-36.9) \mathrm{mg} / \mathrm{dL}, \mathrm{p}<0.001)$. The median albumin level of non-survivors was lower than that of survivors $(2.9(2.3-3.5)$ vs. $3.7(3.2-4.0) \mathrm{g} / \mathrm{dL}, \mathrm{p}<0.001)$. The median BUN/albumin ratio of non-survivors was higher than that of survivors $(13.33(6.69-22.99)$ vs. $6.21(3.83-11.21), p<0.001)$. The ranking of area under the curves was albumin (0.742), BUN/albumin ratio $(0.720)$ and BUN $(0.678)$. The calculated cut-offs were $3.2 \mathrm{~g} / \mathrm{dL}$ for albumin, 10 for BUN/albumin ratio, and $32 \mathrm{mg} / \mathrm{dL}$ for BUN in terms of predicting in-hospital mortality.

Conclusion: In conclusion, hypoalbuminemia detected at ICU admission is associated with in-hospital mortality in critically ill patients. Elevated BUN and BUN/albumin ratio are also predictors of in-hospital mortality in those patients; however, BUN and BUN/albumin ratio are not superior to hypoalbuminemia.
\end{abstract}

Key words: Blood urea nitrogen, albumin, ratio, intensive care, mortality
Cite this article as: Dundar ZD, Kucukceran K, Ayranci MK. Evaluation of The Predictive Power of Blood Urea Nitrogen/Albumin Ratio for in-Hospital Mortality in Critically III Patients. Selcuk Med J 2021;37(4): 294-300
Disclosure: None of the authors has a financial interest in any of the products, devices, or drugs mentioned in this article. The research was not sponsored by an outside organization. All authors have agreed to allow full access to the primary data and to allow the journal to review the data if requested. 


\section{INTRODUCTION}

The intensive care unit (ICU) is a special unit that serves critically ill patients with multiple organ dysfunctions. Patients are usually referred to ICUs from emergency department (ED) or wards of the hospital due to different inclusion criteria for different diseases. Regardless of the diagnosis, it is important to have information about the prognosis of critically ill patients. Many scoring systems have been defined to determine the prognosis of critically ill patients (1). Most of the commonly used scoring systems are based on the principle of observing organ functions (2). Vital findings, laboratory tests, urine output, treatments in critically ill patients provide physicians with additional information to monitor their organ functions. Many biochemical parameters useful for predicting the prognosis in critically ill patients have been described in the literature $(3,4)$.

Albumin is one of the important molecules synthesized by the liver and maintains the oncotic pressure in the vascular compartments. Blood albumin levels have been used for many years to monitor the nutritional status of patients (5). In the literature, studies indicate that albumin is also valuable as a negative acute phase reactant $(6,7)$. Hypoalbuminemia has been associated with increased morbidity and mortality in many diseases such as sepsis, pneumonia, and acute pancreatitis (5-9).

In acute physiological stress, an increase in blood urea nitrogen (BUN) levels can be seen secondary to dehydration and inflammation, and increased hospital/ ICU admission BUN levels in different patient groups have been reported to be useful as an indicator of poor prognosis $(7,10,11)$.

Pan et al. (7) founded that low albumin detected at admission and high BUN levels at follow-up in geriatric intensive care patients were associated with mortality. In the available literature, there is only one study reporting that increased BUN/albumin ratio is directly related to mortality in ICU patients (12). This study by Gundpatil et al. (12) has a small number of cases and the results need to be checked in patients with different profiles. Therefore, in this study, we evaluated the prognostic value of BUN/albumin ratio at ICU admission for in-hospital mortality in critically ill patients.

\section{PATIENTS AND METHODS}

This study was conducted at the ED of a university hospital. The study was design as a retrospective and observational study. Patients admitted to the ED-ICU for 6 months (July - December 2019) were included in the study. Patients were excluded from the study were as follows: patients who did not order BUN or albumin level on ICU admission, patients with endstage renal failure with routine dialysis, patients who transferred to another hospital after ICU admission, and patients were discharged from hospital against to medical advice. The local ethics committee approved the study protocol (decision no. 2020/2651).

The medical charts of all included patients were reviewed. The following information was recorded on a standard data collection forms age, gender, comorbidity, diagnosis, vital signs, BUN, albumin, creatinine levels, and estimated glomerular filtration rate (eGFR) at ICU admission, and in-hospital mortality. The BUN/albumin ratio was calculated using measured BUN (mg/dL) and albumin ( $\mathrm{g} /$ $\mathrm{dL}$ ). The primary outcome was in-hospital mortality. The patients were grouped as survivors and nonsurvivors. The parameters were evaluated between patient groups.

The statistical analyses were performed using SPSS version 20.0 (SPSS Inc., Chicago, IL). Normality analyses of the data were performed using histograms. All parameters were non-normally distributed. The quantitative variables were expressed as the median $(25 \%-75 \%)$, and the categorical variables were expressed as frequency (percentage). The Mann-Whitney $U$ test was used to compare nonnormally distributed quantitative variables between groups. The chi-square and Fisher's exact tests were used to compare the categorical variables between groups.

Receiver operating characteristic (ROC) analysis was performed to determine the in-hospital mortality predictive power of the BUN, albumin, and BUN/ albumin ratio levels. The optimum cut-off levels of the biochemical parameters were determined using Youden's index (sensitivity +1 -specificity). The sensitivity, specificity, and positive and negative predictive values of the parameters were calculated for the optimum cut-off levels. The odds ratios with $95 \%$ confidence intervals $(\mathrm{Cl})$ of the groups categorized by the optimum cut-off values of BUN, albumin, and BAR in predicting in-hospital mortality were calculated. The area under the curve (AUC) and odds ratio values were used to compare the mortality predictive power of the biochemical parameters. $p<0.05$ was considered statistically significant. 


\section{RESULTS}

Atotal of 572 patients was included in the study. The information on excluded patients is shown in Figure 1 (the study flow chart). The median age of included patients was 66 (54-77) years, and $362(63.3 \%)$ of them were male. According to the medical history of patients, $176(30.8 \%)$ of them had hypertension, $152(26.6 \%)$ of them had diabetes mellitus, and 147 $(25.7 \%)$ of them had malignancy. The three leading diagnoses were gastrointestinal bleeding (20.5\%), sepsis $(14.7 \%)$, and multiple trauma $(10.7 \%)$. The overall in-hospital mortality rate was $29.0 \%$ (166 patients). The demographic characteristics of patient populations are shown in Table 1.

The median age of non-survivors was 69.5 (60$79.5)$ years, whereas the median age of survivors was $65(53-76)$ years $(p=0.002)$. There was no difference between survivors and non-survivors in terms of comorbidities ( $p>0.05$ for all) except malignancy $(17.5 \%$ vs. $45.8 \%, p<0.001)$. Non-survivors had lower arterial blood pressure and higher pulse and respiratory rate values than survivors $(p<0.001$,

Table 1. The demographic characteristics of patient population

\begin{tabular}{ll}
\hline Parameters & $\mathbf{n = 5 7 2}$ \\
\hline Age, years & $66(54-77)$ \\
Gender, male & $362(63.3)$ \\
Comorbidities & \\
$\quad$ Hypertension & $176(30.8)$ \\
$\quad$ Diabetes mellitus & $152(26.6)$ \\
$\quad$ Coronary artery disease & $83(14.5)$ \\
$\quad$ Malignancy & $147(25.7)$ \\
COPD/Asthma & $98(17.1)$ \\
Neurovascular disease & $86(15.0)$ \\
Heart failure & $35(6.1)$ \\
Diagnosis & $117(20.5)$ \\
Gastrointestinal bleeding & $84(14.7)$ \\
Sepsis & $61(10.7)$ \\
Multiple trauma & $50(8.7)$ \\
Respiratory insufficiency & $38(6.6)$ \\
Cerebrovascular accident & $36(6.3)$ \\
Encephalopathy & $25(4.4)$ \\
Decreased oral intake & $24(4.2)$ \\
Renal failure & $137(24.0)$ \\
Others & \\
Vital signs on ICU admission & $115(100-135)$ \\
Systolic blood pressure, mmHg & $93(80-108)$ \\
Pulse, beats per minute & $20(17-25)$ \\
Respiratory rate, per minute & $36.4(36.2-36.6)$ \\
Temperature, ${ }^{\circ}$ C & $95(92-97)$ \\
Oxygen saturation, \% & $166(29.0)$ \\
In-hospital mortality & \\
\hline COPD, chronic obstructive pulmonary disease; ICU, intensive care unit \\
Data are presented as n (\%) or median (25\%-75\%)
\end{tabular}

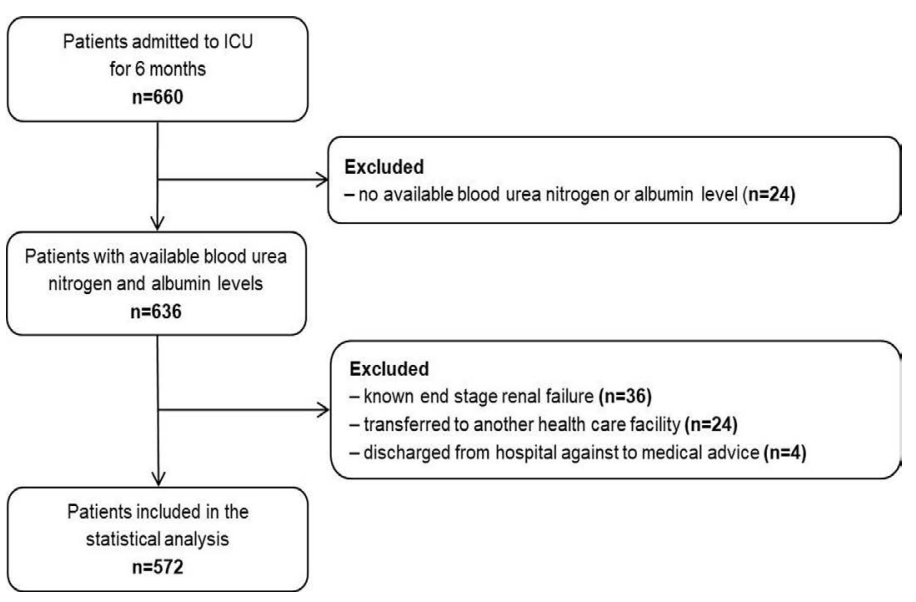

Figure 1. The study flow chart

$p<0.001, p=0.001$, respectively). The median BUN level of non-survivors was higher than that of survivors (38.2 (21.4-59.7) vs. 21.9 (14.9-36.9) $\mathrm{mg} / \mathrm{dL}$, $\mathrm{p}<0.001)$. The median albumin level of non-survivors was lower than that of survivors $(2.9(2.3-3.5)$ vs. 3.7 (3.2-4.0) $\mathrm{g} / \mathrm{dL}, \mathrm{p}<0.001)$. The median BUN/albumin ratio of non-survivors was higher than that of survivors (13.33 (6.69-22.99) vs. 6.21 (3.83-11.21), $p<0.001)$. The comparison of survivors and non-survivors is shown in Table 2.

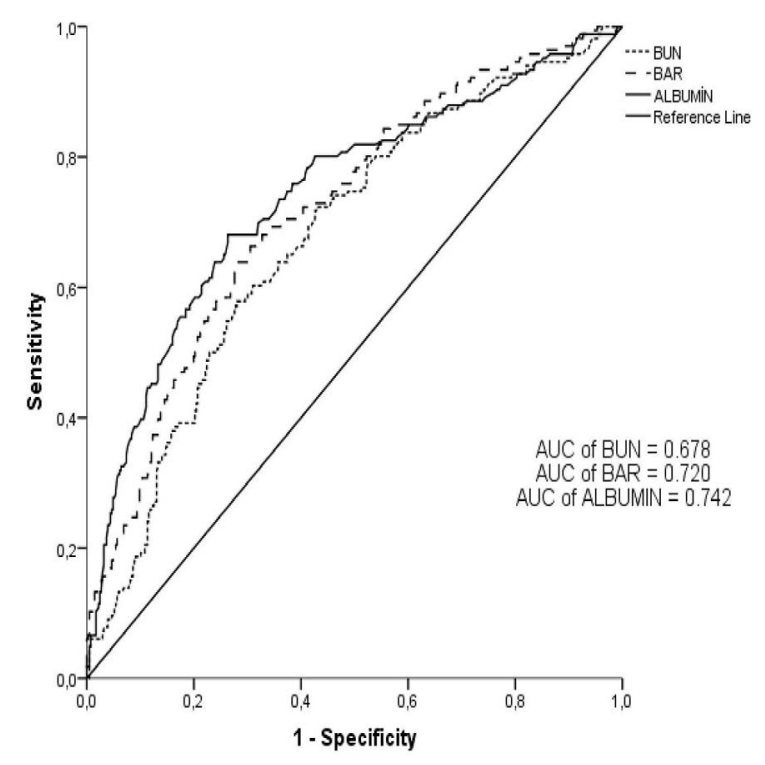

Figure 2. The ROC curves of biomarkers. BUN, blood urea nitrogen, BAR, BUN/albumin ratio 
Table 2. The comparison of parameters between survivors and non-survivors

\begin{tabular}{|c|c|c|c|}
\hline Parameters & $\begin{array}{l}\text { Survivors } \\
(n=406)\end{array}$ & $\begin{array}{l}\text { Non-survivors } \\
(n=166)\end{array}$ & p value \\
\hline Age, years & $65(53-76)$ & $69.5(60-79.5)$ & 0.002 \\
\hline Gender, male & $265(65.3)$ & $97(58.4)$ & 0.124 \\
\hline \multicolumn{4}{|l|}{ Comorbidities } \\
\hline Hypertension & $134(33.0)$ & $42(25.3)$ & 0.070 \\
\hline Diabetes mellitus & $117(28.8)$ & $35(21.1)$ & 0.057 \\
\hline Coronary artery disease & $61(15.0)$ & $22(13.3)$ & 0.585 \\
\hline Malignancy & $71(17.5)$ & $76(45.8)$ & $<0.001$ \\
\hline COPD/Asthma & $74(18.2)$ & $24(14.5)$ & 0.278 \\
\hline Neurovascular disease & $53(13.1)$ & $33(19.9)$ & 0.038 \\
\hline Congestive heart failure & $22(5.4)$ & $13(7.8)$ & 0.275 \\
\hline \multicolumn{4}{|l|}{ Vital signs on ICU admission } \\
\hline Systolic blood pressure, $\mathrm{mmHg}$ & $120(105-140)$ & $105(87.5-126.5)$ & $<0.001$ \\
\hline Pulse, beats per minute & $90(79-104)$ & $102(84-119)$ & $<0.001$ \\
\hline Respiratory rate, per minute & $20(17-24)$ & $24(16-29)$ & 0.001 \\
\hline Temperature, ${ }^{\circ} \mathrm{C}$ & $36.4(36.2-36.6)$ & $36.4(36.2-36.6)$ & 0.418 \\
\hline Oxygen saturation, \% & $95(93-97)$ & $95(91-97)$ & 0.165 \\
\hline Glasgow coma scale score & $15(14-15)$ & $13(8-15)$ & $<0.001$ \\
\hline \multicolumn{4}{|l|}{ Markers } \\
\hline eGFR, mL/min & $79.5(44.6-104.7)$ & $53.1(31.4-77.9)$ & $<0.001$ \\
\hline Creatinine, $\mathrm{mg} / \mathrm{dL}$ & $0.99(0.74-1.43)$ & $1.26(0.87-2.06)$ & $<0.001$ \\
\hline $\mathrm{BUN}, \mathrm{mg} / \mathrm{dL}$ & $21.9(14.9-36.9)$ & $38.2(21.4-59.7)$ & $<0.001$ \\
\hline Albumin, $g / d L$ & $3.7(3.2-4.0)$ & $2.9(2.3-3.5)$ & $<0.001$ \\
\hline BUN/albumin ratio & $6.21(3.83-11.21)$ & $13.33(6.69-22.99)$ & $<0.001$ \\
\hline
\end{tabular}

COPD, chronic obstructive pulmonary disease; eGFR, estimated glomerular filtration rate; BUN, blood urea nitrogen; ICU, intensive care unit Data are presented as $n(\%)$ or median $(25 \%-75 \%)$

The prognostic performances of BUN, albumin, and BUN/albumin ratio in predicting in-hospital mortality are shown in Table 3 . The ranking of AUCs was albumin (0.742), BUN/albumin ratio (0.720) and BUN (0.678) (Figure 2). The AUC of eGFR was 0.640 (0.591-0.689) and the AUC of creatinine was 0.627 (0.576-0.677). The calculated cutoffs were $3.2 \mathrm{~g} / \mathrm{dL}$ for albumin, 10 for BUN/albumin ratio, and $32 \mathrm{mg} / \mathrm{dL}$ for BUN in terms of predicting in-hospital mortality. The sensitivity of BUN/albumin ratio $\geq 10 \mathrm{mg} / \mathrm{g}$ was $64 \%$ and the specificity was $72 \%$. Patients with BUN/ albumin ratio $\geq 10$ on ICU admission had 4.53-times higher risk of in-hospital mortality.

\section{DISCUSSION}

In this study, we found that the BUN level and BUN/albumin ratio of non-survivors were higher and the albumin level of non-survivors was lower than those of survivors. Threshold values for albumin $<3.2$ $\mathrm{g} / \mathrm{dL}, \mathrm{BUN} \geq 32 \mathrm{mg} / \mathrm{dL}$, and BUN/albumin ratio $\geq 10$ can be used to determine the prognosis of critically ill patients. However, results of this study also showed

Table 3. The prognostic performances of parameters in predicting in-hospital mortality

\begin{tabular}{llll}
\hline & BUN/albumin ratio & BUN & Albumin \\
\hline AUC* & $0.720(0.674-0.765)$ & $0.678(0.630-0.726)$ & $0.742(0.695-0.789)$ \\
Cutoff value & $\geq 10$ & $\geq 32 \mathrm{mg} / \mathrm{dL}$ & $<.2 \mathrm{~g} / \mathrm{dL}$ \\
Odds ratio* & $4.53(3.08-6.64)$ & $3.27(2.25-4.75)$ & $5.64(3.81-8.34)$ \\
Sensitivity, \%* & $64(57-70)$ & $58(51-64)$ & $67(60-73)$ \\
Specificity, \%* & $72(69-74)$ & $70(68-73)$ & $74(71-76)$ \\
PPV,\%* & $48(43-53)$ & $44(39-49)$ & $51(46-55)$ \\
NPV, \%* & $83(80-86)$ & $80(77-83)$ & $85(81-87)$ \\
\hline
\end{tabular}

BUN, blood urea nitrogen; AUC, area under the curve; PPV, positive predictive value; NPV, negative predictive value;

* Data presented as value (95\% confidence interval) 
that hypoalbuminemia alone is a more powerful predictor of in-hospital mortality than BUN or BUN/ albumin ratio in those patients.

Albumin is a biomarker that shows both malnutrition and acute inflammatory state (5). Studies have shown that low serum albumin levels are associated with intensive care admission and mortality in different diseases (6,13-16). Again, there are studies in the literature reporting that the prognosis is poor when the albumin level is lower than normal in ICU patients $(7,12)$. Inconclusive results and different opinions have also reported regarding how to cope with hypoalbuminemia in critically ill patients $(5,17,18)$. Our study results show that in-hospital mortality risk increases in patients with hypoalbuminemia at ICU admission. In this study, the threshold was calculated as $3.2 \mathrm{~g} / \mathrm{dL}$ for albumin, and our result reveals that mild hypoalbuminemia at admission in ICU patients also has a remarkable prognostic value. Our comparisons revealed that low albumin level is a stronger predictor of in-hospital mortality than high BUN level. The reason why albumin is a better predictor of mortality compared to BUN may be that the majority of our ICU patients consist of patients with sepsis and gastrointestinal bleeding. In the study conducted by Furukawa et al in 336 patients with sepsis hospitalized in intensive care, they found that hypoalbuminemia reached higher hazard ratios than elevated BUN levels in predicting mortality (19). In the study conducted by Wu et al. (20) in 258 patients with gastrointestinal bleeding, they found that hypoalbuminemia reached higher AUC value than elevated BUN levels in predicting mortality. The fact that approximately half of the non-survivors of this study had malignancy, and malnutrition is a risk factor for mortality in malignancy patients (21) may explain the relationship between hypoalbuminemia and mortality. Although it is unclear whether the exact cause of hypoalbuminemia in ICU patients is nutritional deficiency or the inflammatory effect of acute disease, special attention should be paid to albumin levels in those patients during admission and in the follow-up period. The effects of interventions that will correct hypoalbuminemia such as optimum nutritional support and albumin replacement on patient prognosis should be evaluated with further studies.

BUN is a biomarker that shows renal hypoperfusion, dehydration, and neurohumoral activity (11). It has been shown in many studies that the high BUN level detected at the time of admission to the hospital is associated with mortality $(7,11,22-24)$. In this study, it was determined that non-survivors have higher BUN levels than survivors, and our study results are consistent with the literature. Patients with chronic renal failure requiring dialysis were excluded from our study, and prognostic values of admission BUN, eGFR, and creatinine values were also compared in patients with preserved renal functions in the preacute disease period. In this study, it was found that admission BUN level is more valuable than eGFR and creatinine in predicting in-hospital mortality in our ICU population. There are publications stating that BUN is a better predictor of mortality than creatinine and eGFR in geriatric patients (25). Increased BUN levels that occur in the early period of the critical diseases should be followed carefully and it is important for taking precautions to reduce morbidity and mortality.

The BUN/albumin ratio makes it possible to evaluate kidney functions, inflammation degree and malnutrition at the same time. Study results showing that higher BUN/albumin ratio is associated with higher mortality in patients with pneumonia, gastrointestinal bleeding, and ICU patients $(7,26,27)$. Pan et al. (7) stated that evaluating albumin and BUN levels together in ICU patients was clinically more significant, but in this study, no statistical evaluation was made regarding the BUN/albumin ratio. Gundpantil et al. reported that urea/albumin ratio is more significant than evaluating urea and albumin alone in predicting mortality in ICU patients (12). In this study results, unlike the literature, the AUC of BUN/albumin ratio (0.720) was found to be higher than the AUC of BUN (0.678) but lower than the AUC of albumin (0.742). We think that this difference is due to the patient populations included in those studies. In this study, the factors causing hypoalbuminemia could not be determined in detail, and the possible causes of the differences between those results should be evaluated with further studies. We found the threshold of BUN/albumin ratio as 10 in this critically ill patient population. There is not any comparable BUN/albumin ratio cutoff in the current literature for critically ill patients, however, BUN/ albumin ratio $>7$ was associated with higher mortality in patients with pneumonia (8).

In this study the majority of the study population was male and older people. In addition, the most common comorbidities were hypertension and diabetes mellitus. In the study conducted by Labeau et al. (28) with 13,254 intensive care patients, they found the male sex ratio of the patients to be $61.8 \%$ and the median age to be 64 . In addition, they found 
that the most common comorbidity was diabetes mellitus (28). The results of this study are compatible with the literature.

This study is a single-centered and retrospective study. This design limited the results and their generalizability to whole population. In addition, the treatment protocols were not evaluated in this study. The treatments might directly influence the rate of inhospital. The fact that the study was conducted only in emergency department intensive care patients poses a limitation.

\section{CONCLUSION}

In conclusion, hypoalbuminemia detected at ICU admission is associated with in-hospital mortality in critically ill patients. Elevated BUN and BUN/albumin ratio are also predictors of in-hospital mortality in those patients; however, BUN and BUN/albumin ratio are not superior to hypoalbuminemia.

Conflict of interest: Authors declare that there is no conflict of interest between the authors of the article.

Financial conflict of interest: Authors declare that they did not receive any financial support in this study.

Address correspondence to: Zerrin Defne Dundar, Necmettin Erbakan University, Meram Faculty of Medicine, Department of Emergency Medicine, Konya, Turkey

e-mail: zerdef@hotmail.com

\section{REFERENCES}

1. Salluh JI, Soares M. ICU severity of illness scores: APACHE, SAPS and MPM. Curr Opin Crit Care 2014;20(5):557-65.

2. Karagoz S, Tekdos Seker $Y$, Cukurova $Z$, et al. The effectiveness of scoring systems in the prediction of diagnosis-based mortality. Ther Apher Dial 2019;23(5):41824.

3. Cheng LF, Prasad N, Engelhardt BE. An optimal policy for patient laboratory tests in intensive care units. Pac Symp Biocomput 2019;24:320-31..

4. Bellomo R, Chan M, Guy C, et al. Laboratory alerts to guide early intensive care team review in surgical patients: A feasibility, safety, and efficacy pilot randomized controlled trial. Resuscitation 2018;133:167-72.

5. Vincent JL, Russell JA, Jacob M, et al. Albumin administration in the acutely ill: What is new and where next? Crit Care 2014;18(4):231.

6. Hong W, Lin S, Zippi M, et al. Serum albumin is independently associated with persistent organ failure in acute pancreatitis. Can J Gastroenterol Hepatol 2017;2017:5297143.

7. Pan SW, Kao HK, Yu WK, et al. Synergistic impact of low serum albumin on intensive care unit admission and high blood urea nitrogen during intensive care unit stay on postintensive care unit mortality in critically ill elderly patients requiring mechanical ventilation. Geriatr Gerontol Int 2013;13(1):107-15.
8. Ryu S, Oh SK, Cho SU, et al. Utility of the blood urea nitrogen to serum albumin ratio as a prognostic factor of mortality in aspiration pneumonia patients. Am J Emerg Med 2020;S0735- 6757(20)30118-2.

9. Feng DY, Zhou YQ, Zou XL, et al. Elevated blood urea nitrogento-serum albumin ratio as a factor that negatively affects the mortality of patients with hospital-acquired pneumonia. Can $\mathrm{J}$ Infect Dis Med Microbiol 2019;2019:1547405.

10. Sullivan DH, Sullivan SC, Bopp MM, et al. BUN as an independent predictor of post-hospital-discharge mortality among older veterans. J Nutr Health Aging 2018;22(7):75965.

11. Arihan $\mathrm{O}$, Wernly $\mathrm{B}$, Lichtenauer $\mathrm{M}$, et al. Blood urea nitrogen (BUN) is independently associated with mortality in critically ill patients admitted to ICU. PLoS One 2018;13(1):e0191697.

12. Gundpatil DB, Somani BL, Saha TK, et al. Serum urea: Albumin ratio as a prognostic marker in critical patients with non-chronic kidney disease. Indian J Clin Biochem 2014;29(1):97-100.

13. Wu CY, Hu HY, Huang N, et al. Albumin levels and causespecific mortality in community-dwelling older adults. Prev Med 2018;112:145-51.

14. Jellinge ME, Henriksen DP, Hallas $P$, et al. Hypoalbuminemia is a strong predictor of 30-day all-cause mortality in acutely admitted medical patients: A prospective, observational, cohort study. PLoS One 2014;9(8):e105983.

15. Lyons $O$, Whelan B, Bennett $K$, et al. Serum albumin as an outcome predictor in hospital emergency medical admissions. Eur J Intern Med 2010;21(1):17-20.

16. Robinson R. Low serum albumin and total lymphocyte count as predictors of 30 day hospital readmission in patients 65 years of age or older. PeerJ 2015;3:e1181.

17. Schneider $F$, Dureau AF, Hellé $S$, et al. A pilot study on continuous infusion of $4 \%$ albumin in critically III patients: Impact on nosocomial infection via a reduction mechanism for oxidized substrates. Crit Care Explor 2019;1(9):e0044.

18. Bannard-Smith $J$, Alexander $P$, et al. Haemodynamic and biochemical responses to fluid bolus therapy with human albumin solution, $4 \%$ versus $20 \%$, in critically ill adults. Crit Care Resusc 2015;17(2):122-8.

19. Furukawa M, Kinoshita K, Yamaguchi J, et al. Sepsis patients with complication of hypoglycemia and hypoalbuminemia are an early and easy identification of high mortality risk. Intern Emerg Med 2019;14(4):539-48.

20. Wu KH, Shih HA, Hung MS, et al. The association between blood urea nitrogen to creatinine ratio and mortality in patients with upper gastrointestinal bleeding. Arab J Gastroenterol 2018;19(4):143-7.

21. Hu WH, Eisenstein S, Parry L, et al. Preoperative malnutrition with mild hypoalbuminemia associated with postoperative mortality and morbidity of colorectal cancer: A propensity score matching study. Nutr J 2019;18(1):1-7.

22. Beier K, Eppanapally S, Bazick HS, et al. Elevation of blood urea nitrogen is predictive of long-term mortality in critically ill patients independent of "normal" creatinine. Crit Care Med 2011;39(2):305-13.

23. Tatlisu MA, Kaya A, Keskin M, et al. The association of blood urea nitrogen levels with mortality in acute pulmonary embolism. J Crit Care 2017;39:248-53.

24. Padkins M, Breen T, Anavekar N, et al. Association between albumin level and mortality among cardiac intensive care unit. J Intensive Care Med 2020;885066620963875. 
25. Bae SJ, Lee SH, Yun SJ, et al. Comparison of IVC diameter ratio, BUN/creatinine ratio and $\mathrm{BUN} /$ albumin ratio for risk prediction in emergency department patients. Am J Emerg Med 2021;47:198-204.

26. Kim H, Jo S, Lee JB, et al. Diagnostic performance of initial serum albumin level for predicting in-hospital mortality among aspiration pneumonia patients. Am J Emerg Med 2018;36(1):5-11.
27. Bae SJ, Kim K, Yun SJ, et al. Predictive performance of blood urea nitrogen to serum albumin ratio in elderly patients with gastrointestinal bleeding. Am J Emerg Med 2021;41:152-7.

28. Labeau SO, Afonso E, Benbenishty J, et al. Prevalence, associated factors and outcomes of pressure injuries in adult intensive care unit patients: The DecubICUs study. Intensive Care Med 2021;47(2):160-9. 